\title{
Relative Toxicity of Selected Insecticides against Ladybird Beetle, Propylea sp. under Laboratory Conditions
}

\author{
H. Anjali Patel, C.U. Shinde* and N. Patel Hiral \\ Department of Entomology, N. M. College of Agriculture, Navsari Agricultural University, \\ Navsari - 396450 (Gujarat), India \\ *Corresponding author
}

\section{A B S T R A C T}

\section{Key words \\ Insecticides, Relative toxicity, Ladybird beetle, Propylea sp. \\ Article Info \\ Accepted: \\ 06 August 2018 \\ Available Online: \\ 10 September 2018}

The relative toxicity of different insecticides against adult of Propylea sp. showed that novaluron 10 EC 0.0075 per cent was slightly harmful to adults of Propylea $s p$. While, other remaining insecticides proved to be harmless to adult viz. thiamethoxam $25 \mathrm{WG}$ 0.005 per cent, acetamiprid 20 SP 0.004 per cent, flonicamid 50 WG 0.0075 per cent, clothianidin 50 WDG 0.003 per cent, diafenthiuron 50 WP 0.04 per cent, imidacloprid 17.8 SL 0.005 per cent, spinosad 45 SC 0.02 per cent. Apart from this, azadirachtin 1500 ppm 0.15 per cent showed nil mortality to adults and found safer to the adults of Propylea sp. during present investigation.

\section{Introduction}

Order Coleoptera ranks first among the various bio-control agents. The family "Coccinellidae" of the order Coleoptera is mainly predaceous except subfamily Epilachnae. Coccinellids, popularly known as ladybird beetles are the most beneficial group of insects, playing their important role in checking the aphids and other soft bodied insects in field. The insecticides applied on target pests also influence the non-target insects such as parasitoids and predators prevailing in natural ecosystem. The success of biological control could be enhanced by preventing the careless use of pesticides by having direct and indirect toxic effects on natural enemies. These adverse effects on the bio-agents could be minimized by considering and implementing some technique which may play important role in expanding the function of biological control. One of the important key points in IPM is the proper selection of insecticide that will reduce the target pest but at the same time it should not cause any harmful effect on its natural enemies and pollinators. The aim of pest management is to select such insecticidal that are compatible with bioagents. Keeping this view in mind, the present study was undertaken to know the relative toxicity of various insecticides against adults of Propylea $s p$. under laboratory condition. This finding could be useful in IPM of Lucerne aphid. 


\section{Materials and Methods}

\section{Method of insecticidal application}

The adult of Propylea sp. were obtained from stock culture and relative toxicity test was done at PG Research Laboratory, Department of Agricultural Entomology, N.M. College of Agriculture, Navsari Agricultural University, Navsari (Gujarat). The relative toxicity of various insecticides was evaluated against adults of Propylea $s p$. by using thin dry film method suggested by Paul (1998) with slight modifications. Solutions of different concentration of insecticides were prepared separately in glass jar. A transparent plastic vials $(6 \times 4 \mathrm{~cm})$ with plastic lid converted in to a pesticide testing unit by making a small holes in middle of lid to avoid fumigant effect of insecticides and to provide aeration. For preparation of thin insecticidal film, plastic vials $(6 \times 4 \mathrm{~cm})$ were treated by dipping them in respective insecticidal solution for 5 minutes. In control treatment, only water dipping was done. The insecticidal film formed was dried under the ceiling fan for 15 minutes. Ten treatments were repeated thrice along with control. For this purpose, ten adults of Propylea sp. were released individually per treatment per repetition in each plastic vials (6 $\mathrm{x} 4 \mathrm{~cm}$ ) and test insects were allowed to remain in contact with insecticides dry film for about 45 minutes. Thereafter, adults were transferred to fresh plastic vials $(6 \times 4 \mathrm{~cm})$ individually as per respective treatment along with lucerne aphid as food. Observations on the adult mortality of Propylea $s p$. were recorded at 12, 24, 48 and $72 \mathrm{hrs}$ after release. The moribund adults were also considered as dead. The data obtained on per cent adult mortality of Propylea sp. were converted into Arcsine transformation values and then subjected to statistical analysis for interpretation of the results during the present investigation. A laboratory experiment was conducted using completely randomized design (CRD) with 10 treatments by with three repetitions.

\section{Results and Discussion}

The data in terms of relative toxicity of different insecticides against adults of Propylea sp. after 12, 24, 48 and $72 \mathrm{hrs}$ of insecticidal application are presented in Table 1 and discussed as here under.

The data on per cent mortality obtained $12 \mathrm{hrs}$ after treatment indicated that novaluron $10 \mathrm{EC}$ 0.0075 per cent recorded highest mortality $(43.33 \%)$ followed by thiamethoxam $25 \mathrm{WG}$ 0.005 per cent $(23.33 \%)$ which was at par with acetamiprid 20 SP 0.004 per cent $(20.00$ $\%)$, spinosad 45 SC 0.02 per cent (16.67\%), diafenthiuron 50 WP 0.04 per cent $(13.33 \%$ mortality). However, imidacloprid $17.8 \mathrm{SL}$ 0.05 per cent exhibited lowest mortality $(10.00$ $\%$ ) followed by clothianidin 50 WDG 0.003 per cent $(3.33 \%)$. The data further revealed that no mortality occurred in flonicamid 50 WG 0.0075 per cent $(0.00 \%)$, azadirachtin $1500 \mathrm{ppm} 0.15$ per cent $(0.00 \%)$ and in control $(0.00 \%)$.

The data obtained at $24 \mathrm{hrs}$ after treatments revealed that novaluron $10 \mathrm{EC} 0.0075$ per cent showed highest mortality $(63.33 \%)$. followed by thiamethoxam 25 WG 0.005 per cent $(36.67 \%)$ which was at par with acetamiprid 25 SP 0.004 per cent $(33.33 \%)$. While, the lowest mortality exhibited by imidacloprid 17.8 SL 0.005 per cent (23.44\%) which was at par with diafenthiuron 50 WP 0.04 per cent $(26.67 \%)$ and spinosad 45 SC 0.02 per cent (26.67\%). However, clothianidin 50 WDG 0.003 per cent showed 13.33 per cent mortality to adults. The data further indicated that nil mortality found with flonicamid 50 WG 0.0075 per cent $(0.00 \%)$, azadirachtin $1500 \mathrm{ppm} 0.15$ per cent $(0.00 \%)$ and in control $(0.00 \%)$. It can be seen from the data obtained at $48 \mathrm{hrs}$ after the treatments that 
novaluron 10 EC 0.0075 per cent showed consistently the highest mortality $(66.67 \%)$ followed by thiamethoxam 25 WG 0.005 $(53.33 \%)$. However, the treatment of acetamiprid 25 SP 0.004 per cent $(43.33 \%)$ was at par with spinosad 45 SC 0.02 per cent $(36.67 \%)$. While, the treatment of imidacloprid 17.8 SL 0.005 per cent $(33.33 \%)$ remained at par with diafenthiuron $50 \mathrm{WP}$ 0.04 per cent per cent $(33.33 \%)$ on one side and clothianidin 50 WDG 0.003 per cent $(26.67 \%)$ on other side. flonicamid $50 \mathrm{WG}$ 0.0075 per cent exhibited lowest mortality $(13.33 \%)$ and recorded less toxic to the adults. Azadirachtin $1500 \mathrm{ppm} 0.15$ per cent $(0.00 \%)$ had no mortality and it was at par with control ( $0.00 \%$ mortality).
The cumulative mortality data obtained at 72 hrs after treatment indicated that novaluron 10 EC 0.0075 per cent showed consistently maximum mortality $(73.33 \%)$ followed by thiamethoxam 25 WG 0.005 per cent $(56.67$ $\%$ ) and both were at par with acetamiprid 25 SP 0.004 per cent $(50.00 \%)$. The toxicity of remaining insecticides in descending order was spinosad 45 SC 0.02 per cent $(46.67 \%)>$ diafenthiuron 50 WP 0.04 per cent $(43.33 \%)>$ imidacloprid 17.8 SL 0.005 per cent $(36.67 \%)$ $>$ clothianidin 50 WDG 0.003 per cent $(33.33$ $\%)>$ flonicamid 50 WG 0.0075 per cent (23.33\%). Azadirachtin $1500 \mathrm{ppm} 0.15$ per cent $(0.00 \%)$ and control $(0.00 \%)$ exhibited nil adult mortality during present investigation.

Table.1 Relative toxicity of different insecticides against adult of Propylea $s p$.

\begin{tabular}{|c|c|c|c|c|c|c|c|}
\hline \multirow{2}{*}{$\begin{array}{l}\text { Sr. } \\
\text { No. }\end{array}$} & \multirow[t]{2}{*}{ Treatments } & \multirow{2}{*}{$\begin{array}{c}\text { Conc. } \\
(\%)\end{array}$} & \multicolumn{4}{|c|}{ Mean per cent mortality at different intervals } & \multirow[t]{2}{*}{ Pooled } \\
\hline & & & $12 \mathrm{~h}$ & $24 \mathrm{~h}$ & $48 \mathrm{~h}$ & $72 \mathrm{~h}$ & \\
\hline 1 & Flonicamid $50 \% \mathrm{WG}$ & 0.0075 & $\begin{array}{c}0.91 \\
(0.00) \mathrm{e}\end{array}$ & $\begin{array}{c}0.91 \\
(0.00) \mathrm{f}\end{array}$ & $\begin{array}{c}21.15 \\
(13.33) \mathrm{f}\end{array}$ & $\begin{array}{c}28.78 \\
(23.33) f\end{array}$ & $\begin{array}{l}12.93 \\
(9.17) \mathrm{f}\end{array}$ \\
\hline 2 & Clothianidin $50 \%$ WDG & 0.003 & $\begin{array}{c}6.75 \\
\text { (3.33)de }\end{array}$ & $\begin{array}{c}21.15 \\
(13.33) \mathrm{e}\end{array}$ & $\begin{array}{c}34.00 \\
(26.67) \mathrm{e}\end{array}$ & $\begin{array}{c}35.22 \\
(33.33) \mathrm{e}\end{array}$ & $\begin{array}{c}23.52 \\
(19.17) \text { ef }\end{array}$ \\
\hline 3 & Diafenthiuron $50 \% \mathrm{WP}$ & 0.04 & $\begin{array}{c}21.15 \\
(13.33) b c\end{array}$ & $\begin{array}{c}31.00 \\
(26.67) \mathrm{cd}\end{array}$ & $\begin{array}{c}35.22 \\
(33.33) \mathrm{de}\end{array}$ & $\begin{array}{c}41.15 \\
(43.33) \mathrm{cd}\end{array}$ & $\begin{array}{c}32.12 \\
(29.17) \mathrm{cde}\end{array}$ \\
\hline 4 & Imidacloprid $17.8 \% \mathrm{SL}$ & 0.005 & $\begin{array}{c}15.30 \\
(10.00) \mathrm{cd}\end{array}$ & $\begin{array}{c}28.78 \\
(23.33 \mathrm{~d}\end{array}$ & $\begin{array}{c}35.22 \\
(33.33) \mathrm{de}\end{array}$ & $\begin{array}{c}37.23 \\
\text { (36.67)de }\end{array}$ & $\begin{array}{c}29.12 \\
(25.83) \mathrm{de}\end{array}$ \\
\hline 5 & Spinosad $45 \%$ SC & 0.02 & $\begin{array}{c}23.86 \\
(16.67) b c\end{array}$ & $\begin{array}{c}31.00 \\
(26.67) \mathrm{cd}\end{array}$ & $\begin{array}{c}37.23 \\
(36.67) \mathrm{cd}\end{array}$ & $\begin{array}{c}43.08 \\
(46.67) c\end{array}$ & $\begin{array}{c}33.77 \\
(31.67) \mathrm{cd}\end{array}$ \\
\hline 6 & Novaluron $10 \% \mathrm{EC}$ & 0.0075 & $\begin{array}{c}41.15 \\
(43.33) \mathrm{a}\end{array}$ & $\begin{array}{c}52.78 \\
(63.33) \mathrm{a}\end{array}$ & $\begin{array}{c}54.78 \\
(66.67) \mathrm{a}\end{array}$ & $\begin{array}{c}59.00 \\
(73.33) \mathrm{a}\end{array}$ & $\begin{array}{c}51.91 \\
(61.67) \mathrm{a}\end{array}$ \\
\hline 7 & Acetamiprid $20 \%$ SP & 0.004 & $\begin{array}{c}26.57 \\
(20.00) \mathrm{b}\end{array}$ & $\begin{array}{c}35.22 \\
(33.33) \mathrm{bc}\end{array}$ & $\begin{array}{c}41.15 \\
(43.33) c\end{array}$ & $\begin{array}{c}45.00 \\
(50.00) \mathrm{bc}\end{array}$ & $\begin{array}{c}36.97 \\
(36.67) \mathrm{bc}\end{array}$ \\
\hline 8 & Thiamethoxam 25\% WG & 0.005 & $\begin{array}{c}28.78 \\
(23.33) b\end{array}$ & $\begin{array}{c}37.23 \\
(36.67) \mathrm{b}\end{array}$ & $\begin{array}{c}46.92 \\
(53.33) \mathrm{b}\end{array}$ & $\begin{array}{c}48.85 \\
(56.67) \mathrm{b}\end{array}$ & $\begin{array}{c}40.43 \\
(42.50) \mathrm{b}\end{array}$ \\
\hline 9 & Azadirachtin 1500 ppm & 0.15 & $\begin{array}{c}0.91 \\
(0.00) \mathrm{e}\end{array}$ & $\begin{array}{c}0.91 \\
(0.00) \mathrm{f}\end{array}$ & $\begin{array}{c}0.91 \\
(0.00) \mathrm{g}\end{array}$ & $\begin{array}{c}0.91 \\
(0.00) \mathrm{g}\end{array}$ & $\begin{array}{c}0.91 \\
(0.00) \mathrm{g}\end{array}$ \\
\hline 10 & Control (Water spray) & - & $\begin{array}{c}0.91 \\
(0.00) \mathrm{e}\end{array}$ & $\begin{array}{l}0.91 \\
(0.00) \mathrm{f}\end{array}$ & $\begin{array}{c}0.91 \\
(0.00) \mathrm{g}\end{array}$ & $\begin{array}{c}0.91 \\
(0.00) \mathrm{g}\end{array}$ & $\begin{array}{c}0.91 \\
(0.00) \mathrm{g}\end{array}$ \\
\hline \multirow{2}{*}{\multicolumn{2}{|c|}{$\begin{array}{r}\text { S. Em. } \pm T \\
\text { PxT }\end{array}$}} & \multirow[t]{2}{*}{-} & 3.39 & 1.84 & 1.89 & 1.70 & 2.49 \\
\hline & & & - & - & - & - & 2.31 \\
\hline \multirow{2}{*}{\multicolumn{2}{|c|}{$\begin{array}{r}\text { C.D. at } 5 \% \mathrm{~T} \\
\mathrm{PxT} \\
\end{array}$}} & \multirow[t]{2}{*}{ - } & 9.99 & 5.45 & 5.58 & 5.01 & 7.22 \\
\hline & & & - & - & - & - & 6.81 \\
\hline & C.V. \% & - & 35.29 & 13.34 & 10.76 & 8.67 & 15.24 \\
\hline
\end{tabular}

* Figures outside the parentheses are arcsine transformed values while those inside are original values. 
The result of the pooled analysis at 12, 24, 48 and $72 \mathrm{hrs}$ revealed that significantly highest mortality (61.67\%) of adult of Propylea sp. was recorded in the treatment of novaluron 10 EC 0.0075 per cent and it was followed by thiamethoxam $25 \mathrm{WG} 0.005$ per cent $(42.50$ $\%$ ), acetamiprid 20 SP 0.004 per cent $(36.67$ $\%$ ), spinosad 45 SC 0.02 per cent $(31.67 \%)$, diafenthiuron 50 WP 0.04 per cent $(29.17 \%)$, imidacloprid 17.8 SL 0.005 per cent (25.83 $\%$ ), clothianidin 50 WDG 0.003 per cent (19.17\%), flonicamid $50 \mathrm{WG} 0.0075$ per cent (9.17\%), azadirachtin 1500 ppm 0.004 per cent $(0.00 \%)$ and control $(0.00 \%)$.

Thus, on the basis of above results, it can be concluded that the toxicity to Propylea sp. adults in descending order was novaluron 10 EC 0.0075 per cent $>$ thiamethoxam $25 \mathrm{WG}$ 0.005 per cent $>$ acetamiprid 20 SP 0.004 per cent > spinosad 45 SC 0.02 per cent > diafenthiuron 50 WP 0.04 per cent > imidacloprid 17.8 SL 0.005 per cent > clothianidin 50 WDG 0.003 per cent > flonicamid 50 WG 0.0075 per cent > azadirachtin 1500 ppm 0.15 per cent.

Earlier, Gour and Pareek (2005) who reported that cypermethrin $10 \mathrm{EC}$ was found to be highly toxic (19.00 times) to the adults of Coccinella septempunctata Linn. and rated as highly toxic insecticides. Moreover, imidacloprid 17.8 SL, ethofenprox $10 \mathrm{EC}$ and malathion 50 EC were moderately toxic. However, acephate 75 SP, cartap hydrochloride $50 \mathrm{SP}$ and neem extract 5 per cent were less toxic in nature. Bozsik (2006) who found that pyriproxifen, imidacloprid and $B$. thuringiensis sub sp. tenebrionis were found to be safer for adults of $C$. septempunctata. Pandi (2012) who recorded that azadirachtin $1500 \mathrm{ppm}$ was proved to be safest by causing less than 50 per cent mortality. Whereas, acetamiprid (52.00 \%) and thiamethoxam $(52.00 \%)$ were found to be slightly harmful to $C$. sexmaculata.
Hussain et al., (2017) found that imidacloprid exhibited highest adult mortality of $C$. septempunctata.

Shinde and Radadia (2018) recorded more or less similar observations and revealed that imidacloprid 17.8 SL 0.005, thiamethoxam 25 WG 0.005 and acetamiprid 0.004 per cent were recorded as slightly harmful to the adults of C. sexmaculata (29.33, 42.67 and $48.33 \%$ adult mortality, respectively). However, spinosad 2.5 SL 0.002, endosulfan 35 EC 0.075 , clothianidin 50 WDG 0.003 and indoxacarb $14.5 \mathrm{SC} 0.01$ per cent were moderately harmful $(53.00,55.00,73.67$ and $75.00 \%$ adult mortality, respectively). The treatment of novaluron 10 EC 0.0075 and profenophos 50 EC 0.075 per cent were recorded as completely harmful insecticides to the adults of $C$. sexmaculata by registering 75.00 and 90.33 per cent adult mortality. The findings of the past workers are more or less tally with the present investigation.

\section{Acknowledgement}

The authors are thankful to Professor and Head, Department of Entomology, and Principal, N.M. College of Agriculture, Navsari for providing facility. The authors are grateful to the Director of Research and Dean Post Graduate Studies, Navsari Agricultural University, Navsari for providing necessary facilities.

\section{References}

Bozsik, A., (2006). Susceptibility of adult Coccinella septempunctata (Coleoptera: Coccinellidae) to insecticides with different modes of action. Pest Management Science. 62(7): 651-654. (Fide: https://onlinelibrary.wiley.com/ doi/abs/10.1002/ps.1221)

Gour, I. S., and Pareek, B. L. (2005). Relative toxicity of some insecticides to 
coccinellid, Coccinella septempunctata linn. and Indian honey bee, Apis cerana indica. Indian Journal of Agricultural Research. 39(4): 299-302.

Hussain, M., Mustafa, I., Malik, M. F., Zulifqar, S. and Abbas, Z. (2017). Effect of imidacloprid and bifenthrin on predation efficiency of Coccinella septempunctata (Coleoptera: Coccinellidae) under laboratory conditions. Asian Journal of Agriculture and Biology. 5(3): 126-132.

Pandi, G. G., Paul, B., Shah, V. and Shankarganesh, K. (2013). Relative toxicity of insecticides against Coccinellid beetle, Cheilomenes sexmaculata (Fabricius). Annals of Plant Protection Sciences. 21(1): 17-20.

Paul, A.V.N. (1998). Testing side effects of pesticides on natural enemies of crop pests. A training manual of summer school on "current approaches in biological control of insect pests and disease" during May 26th - June 16th 1998 at Biocontrol Laboratory Division of Entomology, IARI, New Delhi, Pp.112

Shinde, C. U., and Radadia, G. G. (2018). Field-persistent toxicity of various insecticides against potent predator, Cheilomenes sexmaculata (F.). International Journal of Chemical Studies. 6(1): 87-91.

\section{How to cite this article:}

Anjali Patel, H., C.U. Shinde and Patel Hiral, N. 2018. Relative Toxicity of Selected Insecticides against Ladybird Beetle, Propylea sp. under Laboratory Conditions. Int.J.Curr.Microbiol.App.Sci. 7(09): 640-644. doi: https://doi.org/10.20546/ijcmas.2018.709.076 